\title{
Formação do empreendedor social e a educação formal e não formal: um estudo a partir de narrativas de história de vida
}

\author{
Lucimar da Silva Itelvino ${ }^{a}$ \\ Priscila Rezende da Costa ${ }^{b}$ \\ Maria da Glória Gohn ${ }^{c}$ \\ Claudio Ramacciotti d
}

\section{Resumo}

Os empreendedores sociais convertem assuntos sociais em oportunidades, criam negócios e transformam a experiência empreendedora em conhecimento empreendedor. Sendo assim, é relevante entender o processo de formação desse indivíduo como gerador de mudança da sociedade. Esse é, portanto, o objetivo geral desta pesquisa, que é qualitativa, e cujo método envolveu a análise de três narrativas da história de vida de empreendedores, considerados referências no desenvolvimento de projetos sociais de impacto no Brasil, segundo o Prêmio Empreendedor Social, realizado pelo jornal Folha de São Paulo e pela Fundação Schwab. Para a organização das análises, utilizou-se o software ATLAS. Os resultados demonstraram que a formação do empreendedor social está vinculada aos espaços e contextos de aprendizagem, à trajetória de liderança e à motivação para o empreendedorismo social, sendo essas categorias permeadas pela educação formal e não formal.

Palavras-chave: Empreendedor social. Educação formal e não formal. História de vida.

\footnotetext{
a Universidade Nove de Julho. São Paulo, São Paulo, Brasil.

b Universidade Nove de Julho. São Paulo, São Paulo, Brasil.

c Universidade Federal do ABC. Santo André, São Paulo, Brasil.

d Universidade Nove de Julho. São Paulo, São Paulo, Brasil. 


\section{Introdução}

A relação entre o empreendedorismo social e a geração de valor social tem, como figura central, o ator ou sujeito, cujas ações individuais são responsáveis por reconstruir, na coletividade, o processo de socialização, criando qualidade e fortalecendo as relações entre as pessoas. Por ser capaz de converter assuntos relacionados à sociedade em oportunidades, de criar e transformar a experiência empreendedora em conhecimento empreendedor (PHILLIPS et al., 2015; MUÑOZ; KIBLER, 2016; SASTRE-CASTILLO; PERIS-ORTIZ; DANVILADEL VALLE, 2015), o empreendedor social, portanto, torna-se um gerador de transformação da realidade.

Sendo assim, entender a atuação desse indivíduo, a partir da avaliação de seu processo de formação, incluindo a análise conjugada dos seus espaços e contextos de aprendizagem, suas motivações e a trajetória de liderança social traçada, é algo altamente relevante, principalmente porque, na literatura, segundo Bittencourt et al. (2005), há uma lacuna sobre como são desenvolvidas as suas competências.

Diante do exposto, destaca-se a seguinte problemática: Como ocorre o processo de formação do empreendedor social? A fim de responder tal problemática, esta pesquisa pretende, pois, analisar como se dá esse processo e, também, alcançar os seguintes objetivos específicos: verificar e compreender: (a) os espaços e contextos de aprendizagem, (b) a motivação e (c) a trajetória de liderança podem afetar a formação do empreendedor social, além de (d) propor ações didáticas e pedagógicas para que a socialização empreendedora seja concretizada.

A pesquisa se justifica pela importância do empreendedorismo social, enquanto temática de política pública, que tem sido pauta recorrente de discussões, em diferentes estratos da sociedade, devido ao seu potencial de gerar desenvolvimento sustentável e melhorias nas qualidades de vida das pessoas, sobretudo as mais carentes, haja vista a grande demanda que, geralmente, as iniciativas governamentais não conseguem suprir. Em particular, referindo-se à área acadêmica, este trabalho, a partir das narrativas dos empreendedores sociais, preenche a lacuna existente na literatura sobre o assunto, fornecendo elementos didáticos para serem desenvolvidos pelas esferas educacionais e empresariais, a fim de fomentar e formar novos empreendimentos e empreendedores sociais.

\section{Empreendedorismo social}

A julgar pela falta de oportunidade e dificuldade de acesso aos direitos contemplados na constituição brasileira, inúmeros cidadãos integram uma nova 
categoria social - a dos excluídos socialmente. É esse o campo de atuação do empreendedorismo social que, numa primeira análise, parece resultar da junção das expectativas não realizadas do empreendedorismo e da problemática do Terceiro Setor, acarretada, principalmente, pelo desemprego (DRUCKER, 2003).

Para Dornelas (2007),

O empreendedor social tem como missão de vida construir um mundo melhor para as pessoas. Envolve-se em causas humanitárias com comprometimento singular. Tem um desejo imenso de mudar o mundo, criando oportunidades para aqueles que não têm acesso a elas (p. 14)

O empreendedor social busca caminhos para desenvolver o ser humano, de acordo com o que é seu, por direito, resgatando sua cidadania, não somente por ser lei, mas para dar dignidade aos indivíduos. Sua ideologia abarca a sociedade e a sua transformação, de forma a reestruturar a realidade, tornando-a um em espaço em que os cidadãos:

[...] criam novas organizações, abrem seus próprios negócios, vão em busca de recursos, tecem novas redes de colaboração e apoio mútuo, investem seu tempo e seus poucos recursos naquilo em que acreditam e acalentam dia a dia seus sonhos de transformação (MELO NETO; FRÓES, 2002, p. 14).

Sendo assim, "no âmbito do empreendedorismo social, a inovação é maior e melhor, porque desenvolve a projeção de mudanças significativas na sociedade onde está implementada" (MELO NETO; FRÓES, 2002, p. 49). Nessa perspectiva, o empreendedor social desenvolve a capacidade de gerar inovação ao identificar diferentes maneiras para modificar as condições de vida dos excluídos da sociedade. Isso não ocorre como mero trabalho filantrópico, mas como processo de desenvolvimento humanitário.

Em workshop organizado pelos Centros de Estudos do Terceiro Setor (Ceats), da Universidade de São Paulo (USP) e Fundação Getúlio Vargas (FGV/SP), considerados referências para o estudo do empreendedorismo social, alguns dos princípios comuns entre os empreendedores sociais foram identificados. São eles: valorizar e promover a troca de experiências dos participantes, ter visão multidisciplinar, respeitar as diferenças, compreender as origens dos problemas sociais e as políticas públicas, ter compromisso e difundir valores 
como a cidadania e o humanismo, e adotar a postura de facilitador na construção conjunta do conhecimento (TACHIZAWA, 2002).

Para Dornelas (2007), o cerne, no empreendedorismo social, é a relação indissociável entre a realização pessoal/profissional e a possibilidade de melhorar as condições de vida do outro. Para tanto, busca-se criar organizações para preencher as lacunas sociais, anteriormente de responsabilidade do Estado, que sejam geradoras de retorno financeiro (embora esse não seja seu objetivo final), a fim de compartilhar, por conta da aquisição desses novos recursos, a intenção de capacitar o cidadão.

Melo Neto e Fróes (2002) destacam, ainda, que o empreendedor social tem o olhar voltado para a coletividade; fala na primeira pessoa do plural (nós); sente indignação diante da exclusão social, da pobreza e da miséria; e encontra, muitas vezes, no risco de vida do outro, a motivação e o impulso para as suas ações.

A inovação de produtos e serviços, no empreendedorismo social, é decorrente da busca por metodologias que garantam ao ser humano dignidade, por meio da solução para os problemas sociais, sendo sua medida de sucesso o impacto causado na sociedade, pois ele pode ser um agente de mudança, considerando-se a disseminação, a aplicação e a multiplicação de tais inovações em outros grupos na situação de risco social. A satisfação profissional do empreendedor envolvido nesse processo está, então, vinculada à melhoria da qualidade de vida e ao progresso material, espiritual e pessoal de todos os beneficiados pela solução proposta, obtida, geralmente, em função do envolvimento dos membros da comunidade, que participam, integram e promovem, por conseguinte, o desenvolvimento coletivo (VAN DER LINDEN, 2015; MOLDOVAN; BOCOS-BINTINTAN, 2015). Essas ações têm a intenção de retirar o desfavorecido da condição de risco, capacitando-o e lhe oferecendo a oportunidade de reinserção social, por intermédio da educação e da criação de novos espaços de experiência de vida participativa, essenciais à mudança ansiada (VAN DER LINDEN, 2015).

Nesse aspecto, ressalta-se a importância do referencial ético e da figura de liderança do empreendedor social, por sua capacidade de mobilizar pessoas, subordinando a condição econômica ao ser humano. A transformação da realidade social, que é a meta e o seu grande sonho, concretiza-se, por conseguinte, a partir da assunção de uma atitude de inconformismo e de crítica às injustiças sociais (ITURRIOZ; ARAGÓN; NARVAIZA, 2015; WILLEMS, 2015). Complementando essa ideia, Melo Neto e Fróes (2002) apresentam as Dimensões do Empreendedorismo Social no Quadro 1. 
Quadro 1. Dimensões do empreendedorismo social.

\begin{tabular}{|c|c|c|}
\hline Dimensão & Desafio & Objetivo \\
\hline Psicossocial & $\begin{array}{l}\text { 1. Mudar comportamentos; } \\
\text { 2. Instituir processos de participação; } \\
\text { 3. Inovar (vinculada à inserção social); } \\
\text { 4. Engajamento da comunidade; } \\
\text { 5. Incentivar processos responsáveis e éticos. }\end{array}$ & $\begin{array}{c}\text { Desenvolver o sentido de } \\
\text { pertencimento à comunidade, } \\
\text { com a valorização da cultura e } \\
\text { do meio ambiente. }\end{array}$ \\
\hline Cultural & $\begin{array}{l}\text { 1. Preservar a cultura local; } \\
\text { 2. Incentivar e criar cultura } \\
\text { de autossustentabilidade. }\end{array}$ & $\begin{array}{l}\text { Preservar a cultura local } \\
\text { e desenvolver a cultura } \\
\text { de autossustentação. }\end{array}$ \\
\hline Econômica & $\begin{array}{l}\text { 1. Gerar renda; } \\
\text { 2. Criar emprego; } \\
\text { 3. Criar mecanismos de } \\
\text { benefícios e financiamento. }\end{array}$ & $\begin{array}{l}\text { Melhorar a qualidade de vida } \\
\text { da população. }\end{array}$ \\
\hline Política & $\begin{array}{l}\text { 1. Criar novas e desenvolver as atuais } \\
\text { organizações sociais. }\end{array}$ & $\begin{array}{l}\text { Posicionar as organizações } \\
\text { sociais junto à sociedade. }\end{array}$ \\
\hline Ambiental & $\begin{array}{l}\text { 1. Assegurar o uso sustentável dos } \\
\text { recursos naturais; } \\
\text { 2. Reduzir o impacto e criar critérios } \\
\text { para sua utilização. }\end{array}$ & $\begin{array}{l}\text { Assegurar as iniciativas } \\
\text { de preservação do } \\
\text { meio ambiente local. }\end{array}$ \\
\hline $\begin{array}{l}\text { Regulatória/ } \\
\text { Institucional }\end{array}$ & $\begin{array}{l}\text { 1. Incentivar a criação de } \\
\text { políticas públicas para o } \\
\text { empreendedorismo social. }\end{array}$ & $\begin{array}{l}\text { Salvaguardar os } \\
\text { direitos e deveres das } \\
\text { organizações sociais. }\end{array}$ \\
\hline
\end{tabular}

Fonte: Melo Neto e Fróes (2002, p. 2002).

Para Melo Neto e Fróes (2002), a transformação da realidade social está cada vez mais centrada no paradigma vinculado ao empreendedorismo social, que foi sendo (re)construído pela participação e reflexão com as comunidades; com a implementação de soluções inovadoras para a inserção social e o exercício da cidadania; pela promoção de justiça social, geração de renda e produtividade de parcerias entre diferentes setores da sociedade.

Há uma espécie de consenso a respeito do empreendedorismo social, enquanto espaço de atuação, já que ele representa uma nova possibilidade de concretizar, pelo trabalho desenvolvido, a transposição dos agentes beneficiários de um estado à margem da sociedade para a cidadania. Nesse sentido, a inovação social pretende melhorar os resultados sociais e econômicos que realimentam o processo da ação social, agregando a ela parceiros solidários.

Nota-se, portanto, que o empreendedorismo social é uma forma construtiva de geração de capital social, ou seja, um exemplo prático de educação não formal (ITURRIOZ; ARAGÓN; NARVAIZA, 2015). 


\section{Espaços e contextos de formação social}

Segundo Machado (2009), a política pública de educação para jovens e adultos, no Brasil, precisa superar a situação de uma oferta de vagas que não é compatível com a realidade e o anseio do aluno. Outro ponto a se considerar é a necessidade de estreitar a sintonia dos sistemas de ensino das instituições de educação superior com o movimento popular e social.

Dias Sobrinho (2010) também enfatiza que a democratização da educação superior não se limita à ampliação de oportunidades de acesso e criação de mais vagas, mas da geração de qualidade social e da pertinência, ou seja, ela deve ser vista e organizada permanentemente, como um sistema que articula indivíduo e sociedade. Dessa forma, ele passa a ser sujeito de sua própria história, o que, em um contexto educacional, fará o estudante participar coletivamente da construção de um saber, em consonância com suas necessidades (FREIRE, 2001).

Considerando que toda a educação deve ser social, Vieira e Vieira (2016) ressaltam a importância da criação do conceito de Educação Social, cujo objetivo é preparar o indivíduo para a convivência e inserção na sociedade, por meio do desenvolvimento de sua consciência social e de uma identidade pessoal, social e cultural, que será formada ao longo da sua trajetória de vida.

Especificamente, a Lei de Diretrizes e Bases da Educação Nacional - $\mathrm{n}^{\mathrm{o}}$ 9.394, de 20 de dezembro de 1996, estabelece no Título I - Educação, Art. $1^{\circ}$ que "A educação abrange os processos formativos que se desenvolvem na vida familiar, na convivência humana, no trabalho, nas instituições de ensino e pesquisa, nos movimentos sociais e organizações da sociedade civil e nas manifestações culturais". Em complemento, no item II, Dos Princípios e Fins da Educação Nacional, Art. $2^{\circ}$, ela apresenta que "A educação, dever da família e do Estado, inspirada nos princípios de liberdade e nos ideais de solidariedade humana, tem por finalidade o pleno desenvolvimento do educando, seu preparo para o exercício da cidadania e sua qualificação para o trabalho" (BRASIL, 2005).

O recorte acima apresentado reitera a existência de diferentes espaços e contextos de formação, que contribuem para o desenvolvimento do educando e para o exercício pleno da cidadania, concretizando-se com a qualificação para o trabalho. É importante salientar que ao Estado compete o acompanhamento dos processos formativos, realizados nas instituições de ensino e pesquisa, evidenciando que a Escola reflete a formalização da Educação. Por outro lado, a citada Lei confirma 
que, em outros espaços sociais, como a família, grupos de amigos, movimentos sociais e organizações da sociedade civil, também há o desenvolvimento de atividades educativas geradoras de formação.

Isso indica que os processos de formação são construídos e reconstruídos a partir dos conhecimentos acumulados pela educação em diferentes espaços sociais que definem '[...] a forma a que incorporamos tanto os 'saberes' formais e cotidianos quanto os valores e crenças com os quais entramos em contato, e que, por sua vez, definem as nossas possibilidades de ação sobre o mundo" (OLIVEIRA, 2008), Os saberes cotidianos são, assim, internalizados das relações estabelecidas pelo educando, em espaços sociais informais e não formais (JACOBUCCI, 2008). Azevedo (2013) reforça que a educação não formal não deve ser compreendida em oposição à educação escolar, mas pensada como um processo de transformação coletiva.

Conforme Saviani (2005):

[...] quando tomamos a educação, na sua especificidade, como ação propriamente pedagógica, cuja forma mais conspícua se expressa na escola, observamos que esse destacar-se da atividade educativa, em relação aos demais tipos de atividade, não implica necessariamente que as instituições propriamente educativas passem a deter o monopólio exclusivo do exercício do trabalho pedagógico secundário. Na verdade, o que constatamos é uma imbricação de instituições de diferentes tipos, não especificamente educativas que, nem por isso, deixam de cuidar, de algum modo, da educação. Assim, para além da instituição familiar votada, pelas suas próprias características, ao exercício da educação espontânea, vale dizer, do trabalho pedagógico primário, que encontramos instituições como sindicatos, igrejas, partidos, associações de diferentes tipos, leigas e confessionais, as quais, além desenvolver atividade educativa informal, podem, também, desenvolver trabalho pedagógico secundário, seja organizando e promovendo modalidades específicas de educação formal, seja mantendo escolas próprias de caráter permanente (p. 29).

Portanto, pode-se observar a existência de diferentes "espaços" (PETITAT 1 apud GATTI JÚNIOR; INÁCIO FILHO, 2005) ou "espaços de formação"

PETITAT, A. Produção da escola, produção da sociedade: análise sócio histórica de alguns momentos decisivos da evolução escolar no ocidente. Porto Alegre: Artes Médicas, 1995. 
(GRAMSCI ${ }^{2}$ apud NOSELLA; AZEVEDO, 2012, p. 25) social, estabelecidos para suprir as necessidades humanas que, processualmente, surgiram de maneira espontânea e informal, a princípio, e, posteriormente, após determinado estágio de desenvolvimento, foram formalizados e institucionalizados. São esses movimentos da educação que passaram a determinar os espaços sociais de formação dos indivíduos em sociedade.

Considerando que os espaços sociais destinados ao ensino e à aprendizagem resultem em "[...] um processo de crescimento e desenvolvimento de uma pessoa em sua totalidade, abarcando minimamente quatro grandes áreas: a do conhecimento, a do afetivo-emocional, a de habilidades e as atitudes ou valores" (MASSETO, 2003, p. 37), enfatiza-se a possibilidade de que o processo de formação aconteça em diferentes locais e contextos.

Nesse sentido, o espaço da educação informal corresponde "[...] àquele em que os indivíduos aprendem durante seu processo de socialização - em família, bairro, clube, amigos [...] carregado de valores e culturas próprias, de pertencimento e sentimentos herdados" (GOHN, 2006, p. 28). A educação informal é, portanto, espontânea, e muitos dos valores internalizados dos ambientes nos quais ela é promovida resultam das relações sociais herdadas por parentesco e compartilhados por afinidade. Reconhece-se, desta forma, a família, como um importante "espaço" formativo informal da educação, pois: "Nesse espaço de privacidade, prevalecem códigos culturais informais, diferentes daqueles que vigoram no domínio público, regidos por preceitos formais e impessoais" (ROMANELLI, 1995, p. 451). A família, então, enquanto espaço social, corresponde à:

[...] célula institucional em que, teoricamente, eram transmitidos valores e uma herança cultural, eventualmente também material... espaço de socialização. Ela aparece cada vez mais como um espaço em que, dentre muitas outras formas, desenvolvem-se relações afetivas e asseguradoras, que fazem dela o lugar de produção e de valorização de sujeitos; ela é então, nesse caso, um lugar de aprendizagem da autonomia pessoal e de respeito à alteridade (WIEVIORKA, 2006, p. 53).

Por outro lado, na educação não formal “[...] os espaços educativos localizam-se em territórios que acompanham as trajetórias de vida dos grupos e indivíduos, fora das escolas, em locais informais, locais onde há processos interativos intencionais" (GOHN, 2006, p. 29).

2 GRAMSCl, A. Quaderni del carcere. Trans/Form/Ação, v. 2, p. 198-202, 1975. 
A educação não formal designa um processo de várias dimensões tais como: a aprendizagem política dos direitos dos indivíduos enquanto cidadãos; a capacidade dos indivíduos para o trabalho, por meio da aprendizagem de habilidades e/ou desenvolvimento de potencialidades; a aprendizagem e exercício de práticas que capacitam os indivíduos a se organizarem com os objetivos comunitários; a aprendizagem de conteúdos que possibilitem aos indivíduos fazer uma leitura do mundo do ponto de vista de compreensão do que se passa ao seu redor; a educação desenvolvida na mídia e pela mídia, em especial, a eletrônica (GOHN, 2006, p. 29).

Observa-se que, por meio da educação não formal, os movimentos organizados pela sociedade civil - muitos deles de engajamentos políticos e sociais, dedicamse à ação social em espaços públicos, reconstruindo suas histórias e expectativas, transformando-se em processos educativos coletivos, nos quais há, primordialmente, valores que respeitem as diferenças, o reconhecimento do outro e a necessidade de compartilhamento do espaço coletivo (GOHN, 2006).

Nesse contexto, a educação não formal pressupõe construções coletivas, sendo que os problemas do cotidiano constituem meios identificadores das carências dos indivíduos e dos grupos. Com isso, no processo de aprendizagem, "os conteúdos emergem a partir dos temas que se colocam como necessidades, carências, desafios, obstáculos ou ações empreendedoras a serem realizados" (GOHN, 2006, p. 31). Os espaços de formação analisados não pretendem ser excludentes, uma vez que apresentam uma integração possível de competências, habilidades, conhecimentos e valores, oriundos e adquiridos por intermédio da educação formal, informal e não formal. Isso permite a transposição do sujeito de uma condição de exclusão para o exercício da cidadania. O Quadro 2 apresenta as principais características dos diferentes espaços sociais de formação educativa (GOHN, 2006).

Apple e Beane (1999) e Mouffe (1999) reforçaram a importância do desenvolvimento de espaços de educação e de cidadania, dos quais todos podem e devem participar, e cujos princípios são: (a) o vínculo com o entorno, estimulando o diálogo com o ambiente social e a abertura ao conflito, ao debate e à reflexão; (b) a democratização na tomada de decisões, que culmina na criação de políticas de cidadania democrática; (c) o currículo estabelecido como processo democrático, pelo qual os alunos podem ser tornar "intérpretes críticos" da sociedade. O processo de aprendizagem é desenvolvido a partir de situações reais, criadas pelos professores, bem como da reflexão e do debate coletivo; e (d) o compromisso social dos professores, uma vez que a sua formação não se limita aos aspectos didáticos, mas envolve características globais de sua vivência como sujeitos sociais. 
Quadro 2. Principais características dos espaços e contextos de formação.

\begin{tabular}{|c|c|c|c|}
\hline \multirow{2}{*}{$\mathbf{E}$} & \multicolumn{3}{|c|}{ Características Relacionadas aos Contextos de Formação } \\
\hline & Educação formal & Educação informal & Educação não formal \\
\hline Definiç̧ão & $\begin{array}{l}\text { Desenvolvida } \\
\text { nas escolas, } \\
\text { com conteúdos } \\
\text { previamente } \\
\text { demarcados. }\end{array}$ & $\begin{array}{c}\text { Os indivíduos } \\
\text { aprendem durante } \\
\text { seu processo de } \\
\text { socialização - na } \\
\text { família, bairro, clube, } \\
\text { amigos etc. Educação } \\
\text { carregada de valores } \\
\text { e culturas próprias, } \\
\text { de pertencimento } \\
\text { e de sentimentos } \\
\text { herdados. }\end{array}$ & $\begin{array}{l}\text { É aquela que se aprende "no } \\
\text { mundo da vida", via processos } \\
\text { de compartilhamento de } \\
\text { experiências, principalmente } \\
\text { em espaços e ações } \\
\text { coletivos e cotidianos. }\end{array}$ \\
\hline Educador & $\begin{array}{l}\text { Quem educa é } \\
\text { o professor. }\end{array}$ & $\begin{array}{l}\text { Quem educa são os } \\
\text { pais, a família em } \\
\text { geral, os amigos, } \\
\text { os vizinhos, colegas } \\
\text { de escola, a igreja } \\
\text { paroquial, os meios } \\
\text { de comunicação de } \\
\text { massa etc. }\end{array}$ & $\begin{array}{l}\text { Quem educa é o "outro", aquele } \\
\text { com quem o indivíduo interage } \\
\text { ou o grupo ao qual se integra. }\end{array}$ \\
\hline Espaços & $\begin{array}{l}\text { A educação ocorre } \\
\text { nas escolas, } \\
\text { instituições } \\
\text { regulamentadas } \\
\text { por lei, } \\
\text { certificadoras } \\
\text { e organizadas, } \\
\text { segundo as } \\
\text { diretrizes } \\
\text { nacionais. }\end{array}$ & $\begin{array}{l}\text { A educação tem seus } \\
\text { espaços educativos } \\
\text { demarcados por } \\
\text { referências de } \\
\text { nacionalidade, } \\
\text { localidade, idade, } \\
\text { sexo, religião, etnia } \\
\text { etc. A residência, } \\
\text { a rua, o bairro, } \\
\text { o condomínio, o } \\
\text { clube frequentado, } \\
\text { a igreja ou o local } \\
\text { de culto a que se } \\
\text { vincula sua crença } \\
\text { religiosa, o local de } \\
\text { nascimento, etc. }\end{array}$ & $\begin{array}{l}\text { A educação surge dos espaços } \\
\text { educativos que se localizam } \\
\text { em territórios nos quais se dá a } \\
\text { trajetória de vida dos grupos e } \\
\text { indivíduos, fora das escolas, em } \\
\text { ambientes informais, onde há } \\
\text { processos interativos intencionais. }\end{array}$ \\
\hline Contextos & $\begin{array}{l}\text { Pressupõe } \\
\text { ambientes } \\
\text { normatizados, com } \\
\text { regras e padrões } \\
\text { comportamentais } \\
\text { definidos } \\
\text { previamente. }\end{array}$ & $\begin{array}{l}\text { Opera em ambientes } \\
\text { espontâneos, onde } \\
\text { as relações sociais se } \\
\text { desenvolvem segundo } \\
\text { gostos, preferências } \\
\text { ou pertencimentos } \\
\text { herdados. }\end{array}$ & $\begin{array}{l}\text { Ocorre em ambientes e } \\
\text { situações interativas, construídos } \\
\text { coletivamente, de acordo com } \\
\text { diretrizes de determinados } \\
\text { grupos. Usualmente, a } \\
\text { participação dos indivíduos } \\
\text { é optativa, podendo ocorrer, } \\
\text { também, por força de certas } \\
\text { circunstâncias da vivência } \\
\text { histórica de cada um. }\end{array}$ \\
\hline
\end{tabular}

Continua 
Continuação

\begin{tabular}{|c|c|c|c|}
\hline Objetivos & $\begin{array}{c}\text { Relacionam- } \\
\text { se ao ensino e } \\
\text { aprendizagem } \\
\text { de conteúdos } \\
\text { historicamente } \\
\text { sistematizados, } \\
\text { normatizados por } \\
\text { leis, dentre os } \\
\text { quais se destacam } \\
\text { o de formar o } \\
\text { indivíduo como } \\
\text { um cidadão ativo, } \\
\text { desenvolver a } \\
\text { criatividade, a } \\
\text { percepção, a } \\
\text { motricidade, } \\
\text { habilidades e } \\
\text { competências } \\
\text { várias etc. }\end{array}$ & $\begin{array}{c}\text { Relacionam- } \\
\text { se ao processo } \\
\text { de socialização } \\
\text { do indivíduo, } \\
\text { desenvolvendo } \\
\text { hábitos, atitudes, } \\
\text { comportamentos, } \\
\text { modos de pensar e } \\
\text { de se expressar no } \\
\text { uso da linguagem, } \\
\text { conforme valores e } \\
\text { crenças de grupos } \\
\text { frequentados ou aos } \\
\text { quais pertence por } \\
\text { herança, desde o } \\
\text { nascimento. }\end{array}$ & $\begin{array}{l}\text { Relacionam-se ao processo } \\
\text { voltado para os interesses e as } \\
\text { necessidades dos indivíduos, } \\
\text { capacitando-os a se tornarem } \\
\text { cidadãos do mundo, "abrindo } \\
\text { janelas de conhecimento" acerca } \\
\text { do mundo circundante e das } \\
\text { relações sociais a ele equivalentes. } \\
\text { Os objetivos desse tipo de } \\
\text { educação não são dados a priori, } \\
\text { mas construídos ao longo do } \\
\text { processo interativo educativo. A } \\
\text { construção das relações sociais, } \\
\text { em cada grupo social, é baseada } \\
\text { em princípios de igualdade e } \\
\text { justiça social, o que fortalece } \\
\text { o exercício da cidadania. A } \\
\text { transmissão da informação, } \\
\text { bem como a formação política } \\
\text { e sociocultural são metas da } \\
\text { educação não formal, que prepara } \\
\text { os cidadãos, educa o ser humano } \\
\text { para a civilidade, em oposição } \\
\text { à barbárie, ao egoísmo, ao } \\
\text { individualismo etc. }\end{array}$ \\
\hline Resultados & $\begin{array}{c}\text { Espera-se, } \\
\text { sobretudo, } \\
\text { que haja uma } \\
\text { aprendizagem } \\
\text { efetiva, além } \\
\text { da certificação } \\
\text { e titulação que } \\
\text { capacitam os } \\
\text { indivíduos a } \\
\text { seguirem para } \\
\text { graus mais } \\
\text { avançados. }\end{array}$ & $\begin{array}{l}\text { Os resultados não } \\
\text { são esperados, } \\
\text { eles simplesmente } \\
\text { acontecem em função } \\
\text { do desenvolvimento } \\
\text { do senso comum nos } \\
\text { indivíduos, e do senso } \\
\text { orientador das formas } \\
\text { de pensar e agir } \\
\text { espontaneamente. }\end{array}$ & $\begin{array}{l}\text { A consciência e a organização de } \\
\text { como agir em grupos coletivos; } \\
\text { construção e reconstrução de } \\
\text { concepções de mundo e sobre } \\
\text { o mundo; contribuição para } \\
\text { um sentimento de identidade } \\
\text { com uma dada comunidade; } \\
\text { forma o indivíduo para a vida } \\
\text { e suas adversidades, e não } \\
\text { apenas capacita-o para entrar } \\
\text { no mercado de trabalho, resgata } \\
\text { o sentimento de valorização } \\
\text { de si mesmo; dá condições aos } \\
\text { indivíduos para desenvolverem } \\
\text { sentimentos de autovalorização, } \\
\text { de rejeição dos preconceitos que } \\
\text { lhe são dirigidos; suscita o desejo } \\
\text { de luta pelo reconhecimento de } \\
\text { igualdade entre os seres humanos, } \\
\text { dentro de suas diferenças (raciais, } \\
\text { étnicas, religiosas, culturais, etc.); } \\
\text { e aquisição do conhecimento de } \\
\text { sua própria prática (o indivíduo } \\
\text { aprende a ler e a interpretar o } \\
\text { mundo que o cerca). }\end{array}$ \\
\hline
\end{tabular}

Fonte: Gohn (2006). 
Por fim, vale sintetizar que os processos educativos assumem novos significados, de acordo com os espaços sociais (formais, informais e não formais) nos quais eles se desenvolvem e com os quais se relacionam. Essa interação, todavia, não compromete sua identidade, que é mantida, uma vez que as diferenças existentes podem complementar-se. A aproximação de tais processos acontece na medida em que, intencionalmente ou não, seus objetivos (que são, em geral, os da Educação) estejam voltados ao desenvolvimento pleno do ser humano.

\section{Metodologia de pesquisa}

Foi adotada uma abordagem qualitativa que, segundo Richardson (1999), oferece uma compreensão detalhada dos significados e das características situacionais apresentadas pelos objetos da investigação. No caso desta pesquisa, pretende-se entender o processo de formação do empreendedor social, a partir da análise das histórias de vida de André Luis Cavalcanti de Albuquerque, Tião Rocha e Fábio Bibancos de Rosa (cujas características gerais estão apresentadas no Quadro 3), que são três empreendedores sociais premiados pelo jornal Folha de São Paulo e pela Fundação Schwab, pelas inovações de impacto social promovidas no Brasil.

De acordo com Alberti (2004), quando a investigação científica envolve a análise de histórias de vida, ela permite ao autor e à pesquisa extraírem informações e conhecimentos que o indivíduo detém; reconstruir fatos que não estão registrados em outros tipos de fontes; identificar como as pessoas efetuam e elaboram suas experiências; relacionar situações de aprendizagem e decisões; entender como os indivíduos experimentam o passado e interpretam suas ações cotidianas; e delinear a trajetória de vida, com vista a um objeto de estudo, como no caso deste

Quadro 3. Empreendedores sociais analisados.

\begin{tabular}{|c|c|c|c|c|c|}
\hline \multicolumn{3}{|c|}{ Organização } & \multicolumn{3}{|c|}{ Empreendedor } \\
\hline Atividade social & $\begin{array}{c}\text { Ano de } \\
\text { fundação }\end{array}$ & Nome & Nome & Idade & Formação \\
\hline Saúde & 2002 & Turma do Bem & $\begin{array}{c}\text { Fábio Bibancos } \\
\text { de Rosa }\end{array}$ & 43 & Dentista \\
\hline $\begin{array}{l}\text { Educação e } \\
\text { Pesquisa }\end{array}$ & 1984 & \begin{tabular}{|c|} 
Centro Popular \\
de Cultura e \\
Desenvolvimento - \\
CPCD
\end{tabular} & Tião Rocha & 59 & História \\
\hline $\begin{array}{l}\text { Desenvolvimento } \\
\text { e Defesa de } \\
\text { Direitos }\end{array}$ & 2001 & $\begin{array}{l}\text { Terra Nova } \\
\text { Regularizações } \\
\text { Fundiárias }\end{array}$ & $\begin{array}{l}\text { André Luis } \\
\text { Cavalcanti de } \\
\text { Albuquerque }\end{array}$ & 42 & Advogado \\
\hline
\end{tabular}

Fonte: Produzido pelos autores (2017). 
trabalho, cujas histórias são analisadas com fins de compreender o processo de formação do empreendedor social.

Vale destacar a estruturação em "narrativas" de tais histórias, pelas quais os próprios participantes contam suas experiências profissionais e de vida, o que os torna preciosos materiais autobiográficos, uma vez que,

[...] as histórias revelam conhecimento tácito, importante para ser compreendido; têm lugar num contexto significativo, apelam à tradição de contar histórias, o que dá uma estrutura à expressão; geralmente está envolvida uma lição de moral a ser aprendida, podem dar voz ao criticismo de um modo social aceitável; refletem a não separação entre pensamento e ação [...] (GALVÃO, 2005, p. 331).

Considerando os parâmetros acima mencionados, Adam (2008) divide em dois tipos os fatos expostos em narrativas: eventos e ações. As ações caracterizamse pela presença de um agente, o qual provoca ou tenta evitar uma mudança no estado das coisas; os eventos ocorrem sob o efeito de causas, sem a intervenção intencional de um agente. $\mathrm{O}$ autor destaca, nas narrativas, a existência de uma trama dividida em cinco momentos bem característicos, que possibilitam a compreensão do que é narrado: 1) Situação inicial (o ponto de partida da narração); 2) Nó desencadeador (algo que ocorre, e que é responsável pelo desenvolvimento da narrativa); 3) Reação ou avaliação (a atitude do agente da narrativa frente ao nó desencadeador); 4) Desenlace (a resolução); e 5) Situação final.

Com base no que foi descrito por Adam (2008), buscou-se, então, analisar as fases e os eventos marcantes das histórias de vida dos empreendedores sociais, bem como levantar as expressões e atitudes determinantes de sua atuação social. Para tanto, adotou-se a análise do conteúdo, pois ela permite o aprofundamento no mundo dos significados das ações e das relações humanas, possibilitando ao pesquisador ir além do que é tido como resultado claro e manifesto, para obter, por inferência, o que o autor deixou subentendido (FREITAS; JANISSEK, 2000). Ruiz Olabuenaga e Ispizua Uribarri (1989) atestam o emprego da técnica de análise de conteúdo como uma oportunidade para ler e interpretar documentos, garantindo o aspecto qualitativo de uma pesquisa. Para a organização das análises feitas neste trabalho, utilizouse, em ambas as etapas, o software ATLAS. Segundo Lee e Esterhuizen (2000), essa ferramenta auxilia tanto a ordenação quanto a recuperação das informações relacionadas à ideia ou ao conceito subjacente às divisões do sistema de classificação criadas pelo pesquisador, o que é importante para estruturar e validar empiricamente essas categorias no processo de retorno aos dados qualitativos. 


\section{Resultados}

As Figuras 1, 2 e 3, que apresentam os resultados deste trabalho, são representações gráficas das categorias de análise das histórias de vida dos empreendedores sociais estudados, geradas pelo comando de network do software ATLAS.ti. As redes criadas evidenciam as Fases (code family), os Eventos (code) e os Memorandos (memos) característicos de cada momento, sendo que as setas indicam a conexão entre as fases e os eventos, e a relação sequencial estabelecida entre os eventos.

\subsection{Empreendedor social André Luis Cavalcanti Albuquerque}

A história de vida do empreendedor social André Luis Cavalcanti de Albuquerque (ALCA), vencedor do concurso Prêmio Empreendedor Social de 2008, a partir do comando de geração de network do software ATLAS.ti, foi demarcada em três fases, com oito eventos (Figura 1).

Na primeira fase, verificaram-se dois eventos determinantes aos espaços e contextos de aprendizagem de André, incluindo: (E1) graduação em Direito e (E7) participação em seminário internacional e organização de projeto, em parceria com outros cinco países.

$\mathrm{Na}$ segunda fase, destacou-se o evento determinante às suas motivações para o empreendedorismo social, envolvendo: (E2) sensibilização perante a necessidade de exercer força política com a parceria da comunidade, somada à situação de desemprego, culminando na criação de uma empresa social de regularizações fundiárias.

Por fim, a terceira fase é marcada pelos eventos que determinaram a trajetória de liderança social de André, incluindo: (E3) dirigiu o primeiro projeto de regularização fundiária; (E4) criou a instituição Terra Nova Regularizações Fundiárias; (E5) homologou acordo com maior segurança à negociação fundiária; (E6) desenvolveu metodologia de atuação legal para agilizar os processos de regularização fundiária; e (E8) iniciou projetos de reassentamento de famílias em obras de usinas hidrelétricas.

O Quadro 4 destaca trechos da narrativa do empreendedor, de matéria veiculada pelo jornal Folha de São Paulo, que são representativos de cada uma das fases e etapas acima discriminadas, elencadas na Figura 1. 


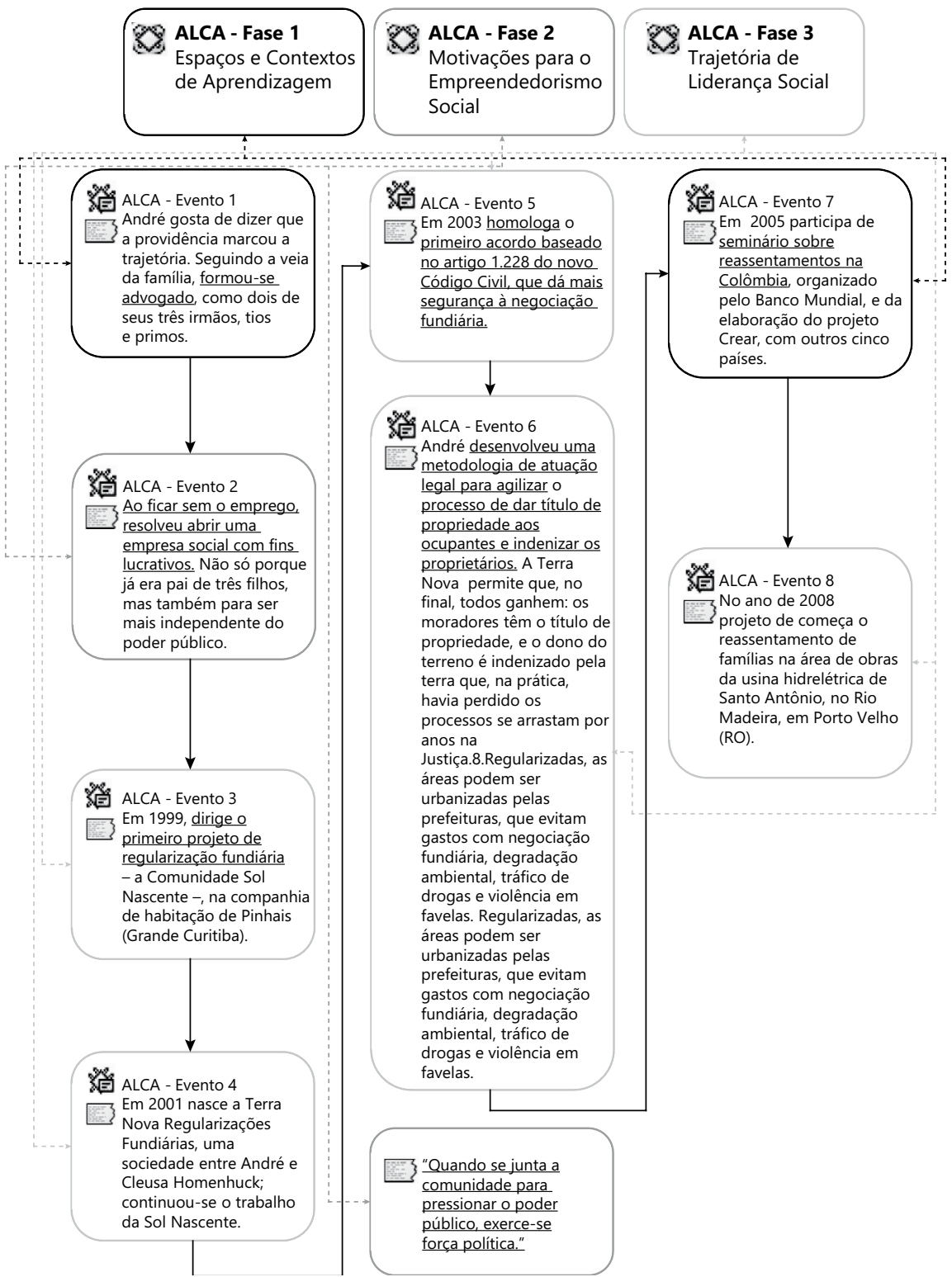

Legenda: ALCA (André Luis Cavalcanti de Albuquerque); Fases (code family); 消 Eventos (code); $[$ Frases de Impacto / Memorandos (memos), $\leftrightarrow \leftrightarrow \rightarrow-\rightarrow$ as setas fazem a conexão entre as fases e os eventos que as compõem; $\rightarrow$ as setas exprimem uma relação de sequência entre os eventos.

Fonte: Produzido pelos autores (2017).

Figura 1. Representação gráfica da história de vida do empreendedor social André Luis Cavalcanti de Albuquerque. 
Percebe-se que as ações empreendedoras são motivadas pela criação de valor social e, quando há, também, criação de valor econômico, ela é vista como um meio necessário para assegurar a viabilidade financeira da atividade social (PHILLIPS et al., 2015; MUÑOZ; KIBLER, 2016; SASTRE-CASTILLO; PERIS-ORTIZ; DANVILA-DEL VALLE, 2016). Isso é comprovado na narrativa de ALCA, quando discorre acerca do empreendimento social Terra Nova:

Quadro 4. Trechos da narrativa de André Luis Cavalcanti Albuquerque relacionados às fases e aos eventos geradas pelo software ATLAS.ti.

\begin{tabular}{|c|c|}
\hline Fases/Eventos & Trechos da narrativa \\
\hline F1/E1 & $\begin{array}{c}\text { "A fala suave e o ouvido atento são os trunfos do curitibano e advogado } \\
\text { de } 42 \text { anos, André Albuquerque, para fazer uma disputa acabar em } \\
\text { acordo, em vez de virar um confronto [...]" }\end{array}$ \\
\hline $\mathrm{F} 2 / \mathrm{E} 2$ & $\begin{array}{c}\text { "E olha que brigas que ele compra não são pequenas, medem-se em } \\
\text { hectares. De um lado estão famílias que moram em áreas ocupadas } \\
\text { irregularmente e que não têm a posse legal dos terrenos; do outro estão } \\
\text { os proprietários das terras./No meio, um advogado que tem o equilíbrio } \\
\text { como norte, serenidade de quem se define como um idealista. Sua ideia } \\
\text { é capitalizar quem não tem capital. 'Eu miro o mundo', diz André. [...] Ao } \\
\text { ficar sem emprego, resolveu abrir uma empresa social com fins lucrativos. } \\
\text { Não só porque já era pai de três filhos, mas também para ser mais } \\
\text { independente do setor público [...]". }\end{array}$ \\
\hline F3/E3 & $\begin{array}{l}\text { "1999 Dirige o primeiro projeto de regularização fundiária - a } \\
\text { Comunidade Sol Nascente [...]". }\end{array}$ \\
\hline F3/E4 & $\begin{array}{l}\text { "[...] Terra Nova Regularizações Fundiárias [empresa que fundou em 2001], } \\
\text { aos sete anos de existência, já somava } 30 \text { mil contratos de regularização [...]". }\end{array}$ \\
\hline F3/E5 & $\begin{array}{c}\text { "A Terra Nova recebe uma porcentagem do valor do terreno que } \\
\text { regulariza e reinveste parte do lucro na comunidade. Os moradores } \\
\text { pagam, em parcelas, pela posse da terra [...] } 2003 \text { Homologa o primeiro } \\
\text { acordo baseado no artigo } 1.228 \text { do novo Código Civil, que dá mais } \\
\text { segurança à negociação fundiária [...]". }\end{array}$ \\
\hline F3/E6 & $\begin{array}{c}\text { "[...] desenvolveu uma metodologia de atuação legal para agilizar o } \\
\text { processo de dar título de propriedade aos ocupantes e indenizar os } \\
\text { proprietários [...] A resolução de disputas tem também outro significado } \\
\text { para André [...] 'O mal não é ganhar dinheiro, e sim acumular riqueza. } \\
\text { O que a empresa angaria tem de ser devolvido, gerar potencial para } \\
\text { atender outros lugares. Se ela tivesse US\$ } 1 \text { bilhão, estaria na África, na } \\
\text { América Latina' [...]". }\end{array}$ \\
\hline F1/E7 & $\begin{array}{l}\text { "2005 Participa de seminário sobre reassentamentos na Colômbia, } \\
\text { organizado pelo Banco Mundial, e da elaboração do projeto Crear, com } \\
\text { outros cinco países Recebe, com a Cohapar (Companhia de Habitação do } \\
\text { Paraná), o prêmio René Frank Habitat, na França, pela melhora de vida em } \\
\text { comunidades pobres". }\end{array}$ \\
\hline F3/E8 & $\begin{array}{l}\text { "Seguindo essa filosofia, o advogado atua no primeiro projeto de } \\
\text { reassentamento integral de famílias em grandes obras. [...] A experiência } \\
\text { inicial se dá com ribeirinhos atingidos pelas obras da usina hidrelétrica } \\
\text { de Santo Antônio, em Porto Velho. Segundo André, é o começo de um } \\
\text { trabalho-modelo que deve ser levado para a África". }\end{array}$ \\
\hline
\end{tabular}

Fonte: Fontes (2008). 
[...] Ao ser contratada, em geral pelo proprietário, a Terra Nova cobra $40 \%$ do valor do terreno, para despesas operacionais e administrativas. O dono fica com $40 \%$, e a comunidade, com $20 \%$, que vão para um fundo - para usá-lo, o gasto deve ser aprovado pelos moradores [...] [A Terra Nova] permite que, no final, todos ganhem: os moradores têm o título de propriedade, e o dono do terreno é indenizado pela terra que, na prática, havia perdido - os processos se arrastam por anos na Justiça [...] Regularizadas, as áreas podem ser urbanizadas pelas prefeituras, que evitam gastos com negociação fundiária, degradação ambiental, tráfico de drogas e violência em favelas [...] [Segundo André,] Quando o ocupante vira dono, pode ter acesso a financiamentos bancários. A comunidade, legalizada, passa a ter direito a melhorias como asfaltar e sanear ruas [...] O conflito entre a vila e o proprietário cria uma atmosfera desfavorável. Quando o dissolvemos, ela se harmoniza energeticamente. O ser humano, equilibrado, prospera [...] (FONTES, 2008).

Pode-se notar que a interação e a mudança, em uma comunidade, são alcançadas mediante um processo de aprendizado que, simultaneamente, resulta de capital social e constrói capital social. E, quanto mais conhecimento e habilidades dos membros da comunidade forem usados de um modo integrado, melhores serão os resultados alcançados (MASKELL, 2000; WILLEMS, 2015).

\subsection{Empreendedor social Tião Rocha}

A história de vida do empreendedor social Tião Rocha (TR), vencedor do concurso Prêmio Empreendedor Social de 2007, a partir do comando de geração de network do software ATLAS.ti, foi demarcada em três fases, com cinco eventos (Figura 2).

Na primeira fase, verificou-se um evento determinante dos espaços e contextos de aprendizagem de Tião, incluindo (E1) graduação no curso de História e a atuação como professor.

Já na segunda fase da sua história de vida, destacou-se o evento relativo às suas motivações para o empreendedorismo social, envolvendo (E2) sensibilização pela transformação do professor em educador e a busca de se fazer educação sem escola.

Por fim, a terceira fase é marcada pelos eventos que determinaram a trajetória de liderança social de Tião, incluindo: (E3) criação de um centro popular de cultura e desenvolvimento; (E4) criação da pedagogia da roda, ampliando a iniciativa pelo nordeste brasileiro e África; (E5) desenvolvimento de outras teorias calcadas no saber popular, como a pedagogia do brinquedo, do sabão e do abraço. 


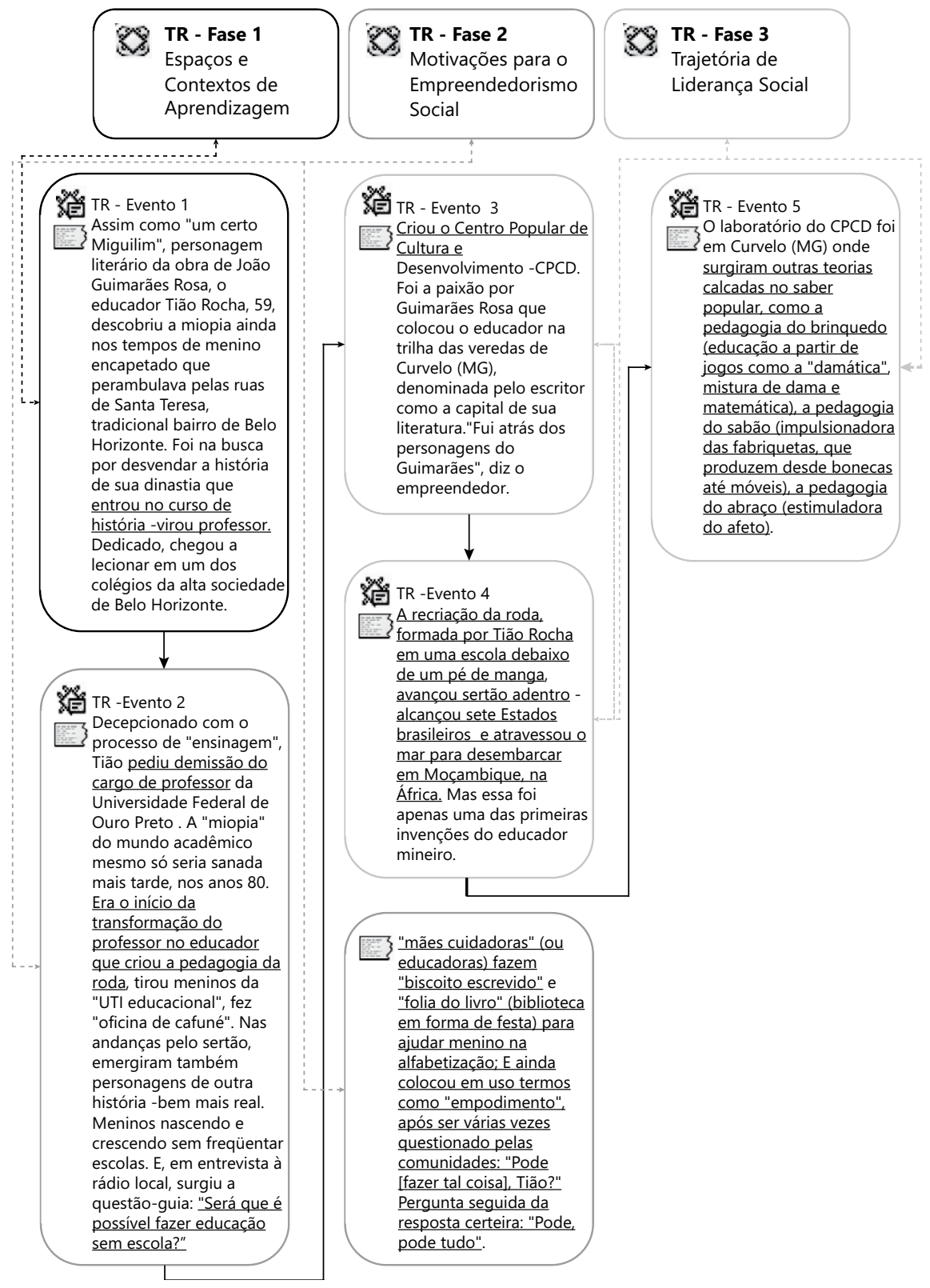

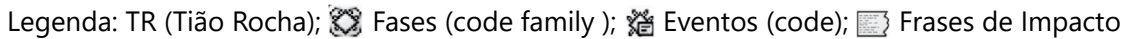
/ Memorandos (memos), $\leftrightarrow \leftrightarrow \Leftrightarrow \leftrightarrow$ as setas fazem a conexão entre as fases e os eventos que as compõem; $\rightarrow$ as setas exprimem uma relação de sequência entre os eventos.

Fonte: Produzido pelos autores (2017).

Figura 2. Representação gráfica da história de vida do empreendedor social Tião Rocha. 
O Quadro 5 destaca trechos da narrativa do empreendedor, de matéria veiculada pelo jornal Folha de São Paulo, que são representativos de cada uma das fases e etapas acima discriminadas, elencadas na Figura 2.

Para Tião, a educação não formal é carregada de valores e culturas próprias, de pertencimento e de sentimentos herdados. O espaço educativo é, portanto, qualquer lugar onde haja "bons educadores" e em que a aprendizagem seja possibilitada:

Educação se faz com bons educadores, e o modelo escolar arcaico aprisiona e há décadas dá sinais de falência. Não precisamos de sala, precisamos de gente. Não precisamos de prédio, precisamos de espaços de aprendizado. Não precisamos de livros, precisamos ter todos os instrumentos possíveis que levem o menino a aprender (CPCD, 2015).

A fala acima é a resposta do empreendedor à pergunta reflexiva feita a si mesmo na Fase 3, Evento 3, de sua trajetória de vida "Será que é possível fazer educação sem Escola?", momento em que ele se depara com crianças nascendo e crescendo sem frequentar uma escola. A partir desse relato, nota-se que o empreendedor social, diante de um contexto desafiante, assume a motivação de atacar as causas dos problemas e produzir mudanças fundamentais no setor social, reforçando os achados de Dees, Emerson e Economy, (2002). Veio a lume, então, a ideia de transformar em "escola", em "sala de aula", qualquer espaço propício ao processo de ensino e aprendizagem.

Assim, fica evidente que o empreendedorismo social é uma forma construtiva de geração de capital social, ou seja, um exemplo prático de educação não formal, conforme destaca Willems (2015), uma vez que promove o desenvolvimento de identidade coletiva em um grupo; a construção e reconstrução de concepção e sobre o mundo; a contribuição para um sentimento de identidade com uma dada comunidade; a formação do indivíduo para a vida e suas adversidades; o resgate do sentimento de valorização de si próprio; e a aquisição, pelos indivíduos, do conhecimento de sua própria prática.

Diante desse contexto, nota-se que o empreendedorismo social pode ser entendido como um processo que cria soluções inovadoras para problemas sociais imediatos e, para tais, mobiliza ideias, capacidades, recursos e arranjos sociais necessários à geração de transformações sociais sustentáveis (ALVORD; BROWN; LETTS, 2004, p. 262). A motivação social é, portanto, explícita, trata-se de como aplicar e dominar as competências, a fim de resolver um problema social (SLOAN; LEGRAND; SIMONS-KAUFMANN, 2014; HAYEK et al., 2015). 
Quadro 5. Trechos da narrativa de Tião Rocha relacionados às fases e eventos geradas pelo software ATLAS.ti.

\begin{tabular}{|c|c|}
\hline Fases/Eventos & Trechos da narrativa \\
\hline $\mathrm{F} 1 / \mathrm{E} 1$ & $\begin{array}{l}\text { "Assim como 'um certo Miguilim', personagem literário da obra de João } \\
\text { Guimarães Rosa, o educador Tião Rocha, 59, descobriu a miopia ainda } \\
\text { nos tempos de menino encapetado que perambulava pelas ruas de } \\
\text { Santa Teresa, tradicional bairro de Belo Horizonte [...] Foi na busca por } \\
\text { desvendar a história de sua dinastia que ingressou no curso de história e } \\
\text { formou-se professor [...]". }\end{array}$ \\
\hline F2/E2 & $\begin{array}{l}\text { "[...] Dedicado, chegou a lecionar em um dos colégios da alta sociedade } \\
\text { de Belo Horizonte [...]. Decepcionado com o processo de 'ensinagem', } \\
\text { Tião pediu demissão do cargo de professor da Ufop (Universidade } \\
\text { Federal de Ouro Preto) [...] E foi a paixão por Guimarães Rosa que colocou } \\
\text { o educador na trilha das veredas de Curvelo (MG), denominada pelo } \\
\text { escritor como a capital de sua literatura. 'Fui atrás dos personagens do } \\
\text { Guimarães', diz o empreendedor, que, na fila do Funrural (antigo fundo } \\
\text { de pensão), encontrou Manuelzão, vaqueiro inspirador do personagem } \\
\text { homônimo da obra roseana [...]". }\end{array}$ \\
\hline F3/E3 & $\begin{array}{l}\text { "[...] Nas andanças pelo sertão, emergiram também personagens de outra } \\
\text { história -bem mais real. Meninos nascendo e crescendo sem frequentar } \\
\text { escolas. E, em entrevista à rádio local, surgiu a questão-guia: 'Será que é } \\
\text { possível fazer educação sem escola?' [...] O desafio impulsionou o nascimento } \\
\text { de uma escola debaixo de um pé de manga. 'Escola' que prescindia de mesa } \\
\text { ou cadeira, lousa ou giz. Mas tinha roda, início do processo de aprendizagem, } \\
\text { mãe ou tio inseridos nas atividades, criança zanzando por todo o bairro, } \\
\text { transformado em sala de aula [...] Nada tinha daquela escola da infância, } \\
\text { quando seus questionamentos não encontravam acolhida na sala de aula } \\
\text { [...] Questionador, ele não entendia por que não estudava a trajetória de } \\
\text { realezas como a de sua tia Etelvina, rainha do congado. 'E quantas realezas } \\
\text { não estão por aí?', pergunta o educador, enquanto olha pela janela as ruas } \\
\text { de terra de Araçuaí [...] Quando seguia o mesmo caminho dos mestres da } \\
\text { infância, o aluno Álvaro Prates provocou o primeiro 'clarão' depois que, } \\
\text { inexplicavelmente, cometeu suicídio. Tião, que conversava com o rapaz } \\
\text { horas a fio sobre revoluções e barricadas, não tinha idéia do motivo da } \\
\text { morte do garoto de } 13 \text { anos. É capaz que o menino tenha indicado os sinais } \\
\text { (ou as 'piscadelas'), mas o professor estava entretido demais em dar conta } \\
\text { do conteúdo escolar. 'Depois já não me interessava mais que os meninos } \\
\text { soubessem tudo sobre a burguesia se eu não conhecesse a vida deles'. E } \\
\text { passou a ensinar e a aprender a partir da sapiência de Álvaros e Etelvinas [...] } \\
\text { [onde] 'mães cuidadoras' (ou educadoras) fazem 'biscoito escrevido' e 'folia } \\
\text { do livro' (biblioteca em forma de festa) para ajudar menino na alfabetização } \\
\text { [...] [Tempos] depois, [Tião] criou o CPCD (Centro Popular de Cultura e } \\
\text { Desenvolvimento) [...]". }\end{array}$ \\
\hline F3/E4 & $\begin{array}{l}\text { "[...] A 'miopia' do mundo acadêmico mesmo só seria sanada mais tarde, } \\
\text { nos anos } 80 \text { [...] Era o início da transformação do professor no educador } \\
\text { que criou a pedagogia da roda, tirou meninos da 'UTI educacional', } \\
\text { fez 'oficina de cafuné' [...] A recriação da roda, formada por Tião Rocha } \\
\text { em uma escola debaixo de um pé de manga, avançou sertão adentro - } \\
\text { alcançou sete Estados brasileiros - e atravessou o mar para desembarcar } \\
\text { em Moçambique, na África [...]". }\end{array}$ \\
\hline
\end{tabular}

Continua 
Continuação

\begin{tabular}{|l|l|}
\hline \multirow{3}{*}{ F3/E5 } & $\begin{array}{l}\text { "[...] Mas essa foi apenas uma das primeiras invenções do educador } \\
\text { mineiro [...] Laboratório do CPCD, foi em Curvelo (MG) onde surgiram } \\
\text { outras teorias calcadas no saber popular, como a pedagogia do } \\
\text { brinquedo (educação a partir de jogos como a 'damática', mistura } \\
\text { de dama e matemática), a pedagogia do sabão (impulsionadora das } \\
\text { fabriquetas, que produzem desde bonecas até móveis), a pedagogia } \\
\text { do abraço (estimuladora do afeto) [...] E ainda colocou em uso termos } \\
\text { como 'empodimento', após ser várias vezes questionado pelas } \\
\text { comunidades: 'Pode [fazer tal coisa], Tião?' Pergunta seguida da } \\
\text { resposta certeira: 'Pode, pode tudo'." }\end{array}$ \\
\hline
\end{tabular}

Fonte: Romeu (2007)

\subsection{Empreendedor social de Fábio Bibancos Rosa}

A história de vida do empreendedor social Fábio Bibancos de Rosa (FBR), vencedor do concurso Prêmio Empreendedor Social de 2006, a partir do comando de geração de network do software ATLAS.ti, foi demarcada em três fases, com oito eventos.

Na primeira fase, verificou-se um evento determinante dos espaços e contextos de aprendizagem de Fábio, incluindo (E2) decisão de se tornar dentista para conciliar a habilidade manual à vontade de ajudar os outros.

Já na segunda fase da sua história de vida, destacou-se o evento determinante às suas motivações para o empreendedorismo social, envolvendo (E1) sensibilização pelas condições das comunidades carentes, dada a proximidade vivenciada na infância, despertando interesse pela ação social.

Por fim, a terceira fase é marcada pelos eventos que determinaram a trajetória de liderança social de Fábio, incluindo: (E3) vivência da democracia na universidade e o despertar de forças para lutar por justiça; (E4) vivência da ação social na universidade e inquietação gerada pela busca de melhoria; (E5) transformação da realidade que o cerca e idealização do projeto Adote um Sorriso, em parceria com a ABRINQ; (E6) desenvolvimento da Turma do Bem, uma rede de voluntários que oferecem tratamento dentário e trocam correspondência com crianças de abrigos; (E7) treino de coordenadores regionais para replicação das estratégias e dos projetos; (E8) replicação e continuidade dos projetos de atendimento e acompanhamento de adolescentes e crianças até os 18 anos, em consultórios particulares (Figura 3). 


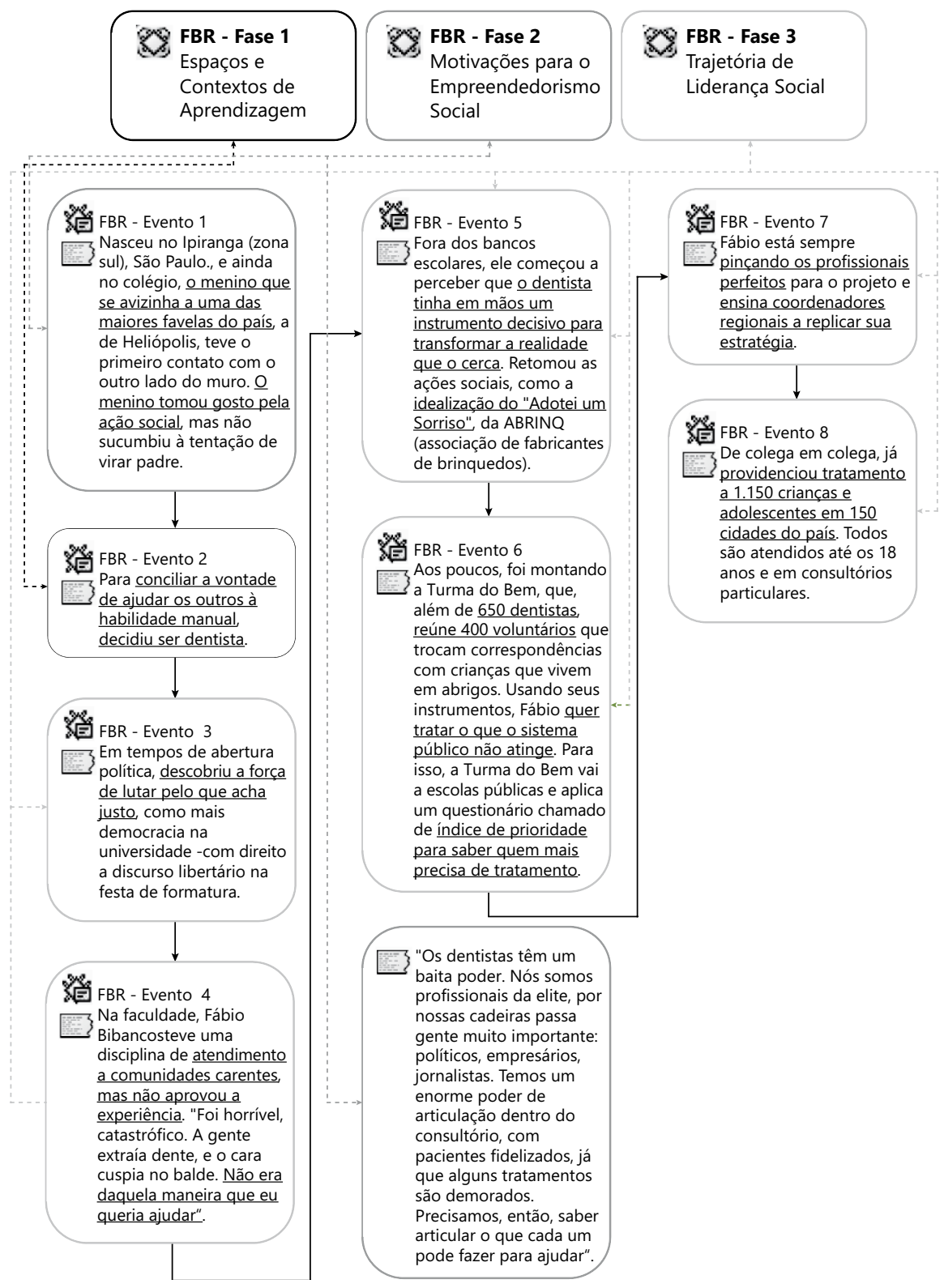

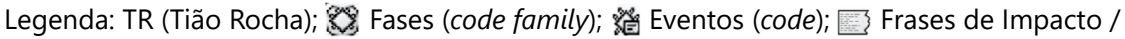
Memorandos (memos) $\leftrightarrow \leftrightarrow \rightarrow \leftrightarrow$ as setas fazem a conexão entre as fases e os eventos que as compõem; $\rightarrow$ as setas exprimem uma relação de sequência entre os eventos.

Fonte: Elaborado pelos autores (2017).

Figura 3. Representação gráfica da história de vida do empreendedor social Fábio Bibancos de Rosa. 
O Quadro 6 destaca trechos da narrativa do empreendedor, de matéria veiculada pelo jornal Folha de São Paulo, que são representativos de cada uma das fases e etapas acima discriminadas, elencadas na Figura 3.

Na história de vida do empreendedor social Fábio, além da educação formal em odontologia, foi também marcante na educação não formal, cujos processos de aprendizagem foram interativos e intencionais, ou seja, ocorreu uma intencionalidade na ação, no ato de participar, de aprender e de transmitir ou trocar saberes. Além disso, os seus objetivos não foram dados a priori-eles se construíram a partir de processo coletivo que gerou "capital social", conforme destacam Gohn (2006) e Willems (2015).

Diante desse contexto, nota-se que os empreendedores sociais são inovadores sociais por excelência, motivados para transformar a sociedade e serem agentes dessa mudança; ademais, adotam uma missão para criar e sustentar o valor social (DEES, 1998; PHILLIPS et al., 2015; MUÑOZ; KIBLER, 2016). Vale destacar que as práticas inovadoras de atuação dos empreendimentos sociais necessitam ser compartilhadas por todos os atores envolvidos. Isso demanda um empreendedor social com habilidades relacionais mais desenvolvidas (SOUSA et al., 2013).

\section{Considerações finais e proposições}

Os resultados demonstraram que a formação do empreendedor social está vinculada aos espaços e contextos de aprendizagem, à trajetória de liderança social e à motivação para o empreendedorismo social, sendo que essas categorias são permeadas pela educação formal e não formal (Figura 4).

Em relação à categoria espaços e contextos de aprendizagem, nota-se a presença de uma formação definida como "formal", pois os empreendedores analisados possuem formação universitária. A importância desse fator se dá pela necessidade do empreendedor adquirir habilidades e competências profissionais, por meio de um processo educacional que leve em consideração um conjunto de conhecimentos acadêmicos, orientando o desenvolvimento do empreendedorismo. Esse conhecimento formal, no entanto, não é suficiente para que uma pessoa ultrapasse o status de empreendedor para se tornar empreendedor social (Figura 4).

No contexto da categoria trajetória de liderança social, destaca-se que o empreendedor social precisa também de experiências vividas na coletividade, ou seja, no "espaço não formal", experimentando o voluntariado e sentindo a vontade de fazer algo, a fim de atenuar e/ou sanar problemas sociais, por meio 
Quadro 6. Trechos da narrativa de Fábio Bibancos de Rosa relacionados a fases e eventos gerados pelo software ATLAS.ti.

\begin{tabular}{|c|c|}
\hline Fases/eventos & Trechos da narrativa \\
\hline $\mathrm{F} 2 / \mathrm{E} 1$ & $\begin{array}{l}\text { "Ainda no colégio, o menino nascido no lpiranga (zona sul), que se avizinha a } \\
\text { uma das maiores favelas do país, a de Heliópolis, teve o primeiro contato com o } \\
\text { outro lado do muro. 'Estudei em colégio jesuíta e uma hora precisava escolher } \\
\text { entre esporte e trabalho social. Detestava ficar com a turma dos atletas, toda } \\
\text { aquela competitividade, então entrei para a alternativa, que tocava violão e ia } \\
\text { para a favela'[...] O menino tomou gosto pela ação social [...]". }\end{array}$ \\
\hline F1/E2 & $\begin{array}{c}\text { [Fábio nasceu no Ipiranga, zona sul de São Paulo] "[...] Para conciliar a } \\
\text { vontade de ajudar aos outros a habilidade manual, decidiu ser dentista [...]". }\end{array}$ \\
\hline F3/E3 & $\begin{array}{l}\text { "[...] Em tempos de abertura política, descobriu a força de lutar pelo que acha } \\
\text { justo, como mais democracia na universidade, com direito a discurso libertário } \\
\text { na festa de formatura [...] 'Na faculdade, a gente era obrigado a fazer aquilo } \\
\text { e não tinha muito respaldo científico para discutir. Fui atrás de aprender para } \\
\text { melhorar e poder dar informação para que as pessoas possam decidir o que } \\
\text { é melhor para si, em vez de ficarem totalmente à mercê de um diagnóstico' [...]". }\end{array}$ \\
\hline F3/E4 & $\begin{array}{c}\text { "[...] Na faculdade, Fábio Bibancos teve uma disciplina de atendimento } \\
\text { a comunidades carentes, mas não aprovou a experiência. 'Foi horrível, } \\
\text { catastrófico. A gente extraía dente, e o cara cuspia no balde. Não era } \\
\text { daquela maneira que eu queria ajudar' [...]". }\end{array}$ \\
\hline F3/E5 & $\begin{array}{c}\text { "[...] 'Todos merecem tratamento, mas não em qualquer lugar. Quero } \\
\text { que os dentistas atendam em seu consultório, onde têm os melhores } \\
\text { equipamentos e oferecem qualidade máxima' [...] Retomou as ações } \\
\text { sociais, como a idealização do "Adotei um Sorriso", da Abrinq (associação } \\
\text { de fabricantes de brinquedos) [...]". }\end{array}$ \\
\hline F3/E6 & $\begin{array}{l}\text { "[...] Fora dos bancos escolares, ele começa a perceber que o dentista } \\
\text { tinha em mãos um instrumento decisivo para transformar a realidade } \\
\text { que o cerca [...] 'Nós somos profissionais da elite, por nossas cadeiras } \\
\text { passa gente muito importante: políticos, empresários, jornalistas. Temos } \\
\text { um enorme poder de articulação dentro do consultório, com pacientes } \\
\text { fidelizados, já que alguns tratamentos são demorados. Precisamos, } \\
\text { então, saber articular o que cada um pode fazer para ajudar', raciocina } \\
\text { [...]. Perfeccionista, saiu por achar que podia melhorar e, aos poucos, } \\
\text { foi montando a Turma do Bem, que, além de } 650 \text { dentistas, reúne } 400 \\
\text { voluntários que trocam correspondências com crianças que vivem em } \\
\text { abrigos [...] 'O foco não é a boca, mas o bem-estar do indivíduo', diz [...]". }\end{array}$ \\
\hline F3/E7 & $\begin{array}{l}\text { "[...] Usando seus instrumentos, Fábio quer tratar o que o sistema público } \\
\text { não atinge. Para isso, a Turma do Bem vai a escolas públicas e aplica um } \\
\text { questionário chamado de índice de prioridade para saber quem mais precisa de } \\
\text { tratamento [...]. Formado, não demorou para voltar a ter um pé em cada mundo. } \\
\text { Seu amigo Marco Ricca, ator, foi trazendo a seu consultório alguns colegas de } \\
\text { profissão. O boca a boca cresceu tanto que Fábio ganhou o apelido de 'dentista } \\
\text { das estrelas' [...] Professor, autor de livros e mediador de um 'vídeochat', } \\
\text { aposta no conhecimento para melhorar a vida das crianças que atende. [...] } \\
\text { Fábio está sempre pinçando os profissionais perfeitos para o projeto e ensina } \\
\text { coordenadores regionais a replicar sua estratégia. 'Sabe aquele encrenqueiro, } \\
\text { aquele que não se conforma? Esse que tem veia para o projeto'. [...]". }\end{array}$ \\
\hline F3/E8 & $\begin{array}{c}\text { "[...] De colega em colega, já providenciou tratamento a } 1.150 \text { crianças e } \\
\text { adolescentes em } 150 \text { cidades do país. Todos são atendidos até os } 18 \text { anos } \\
\text { e em consultórios particulares. [...]". }\end{array}$ \\
\hline
\end{tabular}

Fonte: Fontes (2006). 
de ações inovadoras. A liderança para o empreendedorismo social amplia o sentido de pertencimento e resulta em ações sociais que atendem às necessidades coletivas (Figura 4).

E finalmente, em relação à categoria motivação para o empreendedorismo social, o sentir-se motivado é o combustível que gera a energia suficiente para "o agir" diante de uma situação-problema, identificada no meio social, e da qual o empreendedor social se sente parte, sendo o fator motivacional central aprender com a vida e na vida, experimentando situações e compartilhando-as com os outros. Nesse sentido, o empreendedor social, ao construir e consolidar sua identidade como agente de transformação, também dá sentido e passa a ser referência para a construção de uma identidade coletiva (Figura 4).

O indivíduo que pretende inserir-se no universo do empreendedorismo social, necessariamente precisa de experiências, que só são adquiridas em contextos interativos como, por exemplo, nas organizações sociais que, costumeiramente, promovem às pessoas uma vivência de situações de cidadania, despertando um

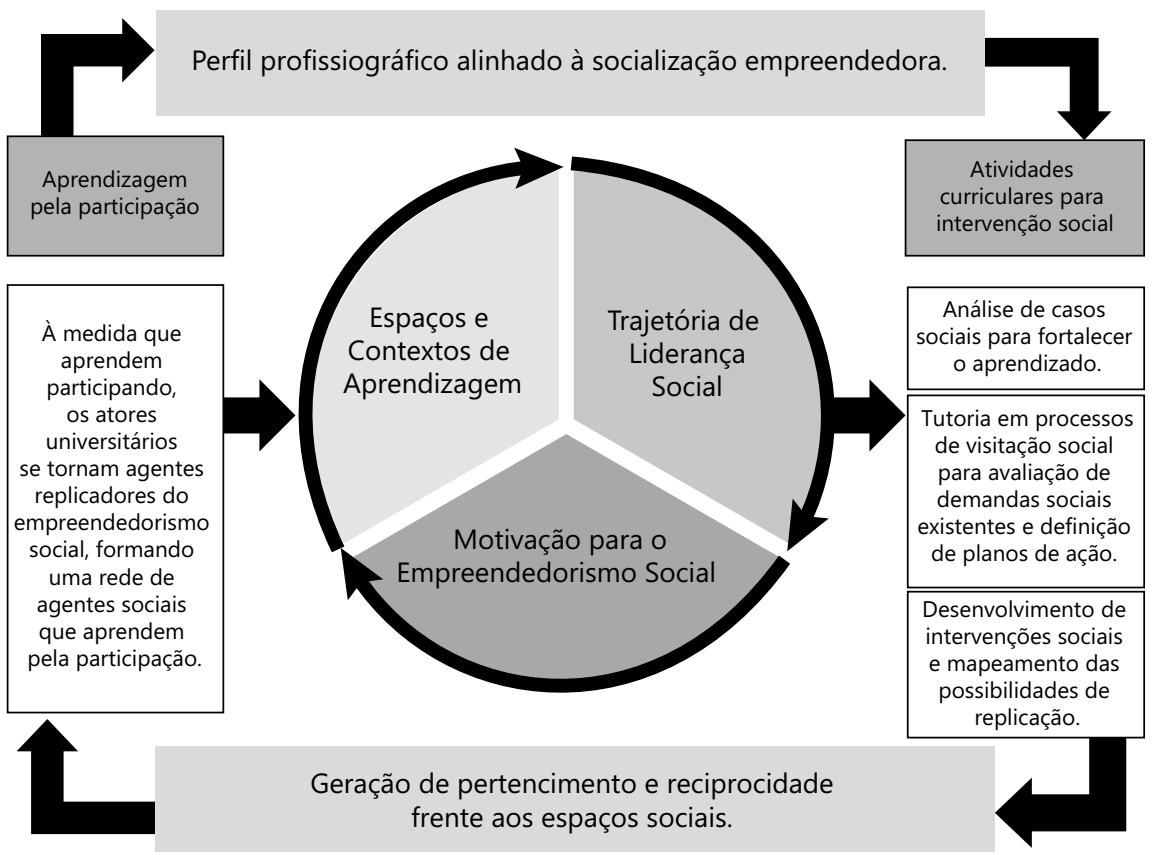

Fonte: Elaborado pelos autores (2017).

Figura 4. Socialização empreendedora a partir da Educação Formal e Não Formal. 
senso de urgência em relação ao próximo, que se dá, especialmente, no espaço de formação não formal (Figura 4).

Adicionalmente, vale frisar que é considerável o aumento do número de egressos do Ensino Superior no Brasil, em decorrência das políticas de inclusão. No entanto, a absorção pelo mercado não avançou no mesmo ritmo, demandando, portanto, a introdução da visão empreendedora e inovadora nos cursos de graduação. De forma específica, assumem relevância as práticas que possibilitam aos estudantes o contato com o ambiente social com vistas a desenvolver uma postura empreendedora e inovadora durante a sua formação, complementando, assim, a visão estritamente acadêmica da formação universitária. Como consequência progressiva, tais iniciativas poderiam alterar o perfil do empresário brasileiro, possibilitar a geração de novos negócios, bem como a criação de produtos e serviços com maior valor agregado, estimulando o desenvolvimento tecnológico e social do país (PEREIRA et al., 2016).

Destaca-se, também, que a real democratização da educação superior no Brasil requer uma mudança de mentalidade em relação ao sentido da escola, ao papel que ela pode assumir, no âmbito da comunidade, e ao significado do ato de educar e aprender para os próprios jovens e adultos que, muitas vezes, não veem mais sentido na educação, conforme apontam Machado (2009) e Dias Sobrinho (2010). Sendo assim, a superação desses desafios está atrelada a uma formação pautada no pertencimento, no empoderamento do indivíduo e na geração de transformação social.

Portanto, mais do que uma matriz curricular com disciplinas sobre "Empreendedorismo", "Terceiro Setor" e "Economia solidária", é importante promover a "Socialização Empreendedora" dos cursos universitários, a partir de ações didáticas capazes de integrar espaços e contextos formais e não formais, além de possibilitar o desenvolvimento da liderança profissional e do senso coletivo, por meio de atividades práticas de intervenção social (Figura 4).

Especificamente sobre a proposição de "Socialização Empreendedora" dos cursos universitários, destacam-se as seguintes ações didáticas e pedagógicas sugestivas (Figura 4):

1. A proposta pedagógica (institucional) das Instituições de Ensino Superior poderá basear-se na aprendizagem pela participação, ou seja, atores universitários (estudantes e professores) poderão aprender essencialmente pela participação colaborativa em múltiplos ambientes de aprendizagem social (não 
formal), como núcleos de capacitação social, incubadoras sociais, comunidades locais e organizações sociais. À medida que aprendem participando, esses atores se tornam agentes replicadores do empreendedorismo social, formando uma rede de agentes sociais.

2. Cada curso universitário poderá avaliar também as sinergias e possibilidades de absorção das atitudes que são decisivas à formação do empreendedor social, atualizando, portanto, o perfil profissiográfico do aluno egresso, sendo necessário considerar, com parcimônia, as seguintes atitudes mapeadas nas histórias de vida analisadas em profundidade no presente estudo:

2.1 Atitudes em prol da aprendizagem social: (a) buscar a autossuperação, seja ela física, intelectual ou social; (b) estabelecer referência familiar, paterna ou de outra natureza, como exemplo de cidadania e ética; (c) firmar parcerias para geração de aprendizado coletivo; (d) exercer o voluntariado para aprender participando.

2.2 Atitudes em prol da motivação social: (a) sentir gratidão em relação à vocação de empreender socialmente; (b) atribuir determinação para concretizar as ações socais; (c) ter otimismo frente aos espaços e contextos de futura intervenção; (d) converter a indignação perante as desigualdades sociais em ações de intervenção efetivas; (e) canalizar a inquietação social na busca de produtos, processos ou métodos inovadores capazes de ampliar as intervenções sociais; (f) traduzir, por meio de ações, a sua preocupação contínua com a realidade social.

2.3 Atitudes em prol da liderança: (a) formalizar ações e projetos de intervenção em organizações sociais; (b) estabelecer justiça, a partir de ações e projetos sociais; (c) gerar permanente transformação social para autonomia dos indivíduos; (d) desenvolver continuamente ações inovadoras para a intervenção social e ambiental; (e) ampliar, de forma contínua, a intervenção social para outros contextos e localidades.

3. Num segundo momento, será necessário avaliar as disciplinas de formação profissional com maiores possibilidades de aderência e interdisciplinaridade ao empreendedorismo social, que poderão prever atividades de ensino, pesquisa e/ou extensão capazes de promover reflexão e ação sobre as necessidades e oportunidades de inovação social regionais, nacionais ou mesmo internacionais. As atividades pedagógicas de "Socialização Empreendedora", realizadas particularmente nas disciplinas, poderão incorporar as seguintes abordagens: 
3.1 Os espaços e contextos das atividades pedagógicas poderão compreender análises de casos sociais fictícios para fortalecer o aprendizado e, posteriormente, os estudantes poderão ser tutorados em processos de visitação social para avaliação de demandas sociais existentes e definição de planos de ação.

3.2 O significado das atividades pedagógicas poderá levar em consideração o pertencimento e a reciprocidade dos estudantes frente aos espaços sociais, foco das intervenções, sendo importante que a escolha desses espaços seja compartilhada para gerar sentido e valor à aprendizagem.

3.3 Os resultados esperados das atividades pedagógicas poderão prever o desenvolvimento de intervenções sociais e, por fim, o mapeamento das possibilidades de replicação das intervenções sociais geradas em outras localidades.

Tendo em vista que o conhecimento é um processo continuamente em construção, a proposta de "Socialização Empreendedora" e suas ações didáticas podem e devem ser, ainda, objeto de novos estudos em prol da formação do empreendedor social. Em relação às limitações da presente pesquisa, fica estabelecida a necessidade de um olhar com a devida parcimônia, não sendo possível realizar generalizações acerca dos resultados obtidos, que estão explicitamente relacionados aos empreendedores sociais analisados. 


\title{
Formation of the social entrepreneur and formal and non-formal education: $A$ study from narratives of life story
}

\begin{abstract}
Social entrepreneurs convert social affairs into opportunities, create businesses, and transform entrepreneurial experience into entrepreneurial knowledge. Thus, the understanding of the social entrepreneur's formation as a generator of social transformation is relevant. From this context, the general objective is to understand how the process of formation of the social entrepreneur occurs. To do this, a qualitative research was carried out and the research method involved the analysis of three life story narratives of entrepreneurs considered a reference in the development of social projects of impact in Brazil, according to the Social Entrepreneur Award conducted by the Folha de São Paulo newspaper and the Schwab Foundation. For the organization of the analysis, the ATLAS software was used. The results showed that the formation of the social entrepreneur is linked to the spaces and contexts of learning, the leadership trajectory and the motivation for social entrepreneurship, and these categories are permeated by formal and non-formal education.
\end{abstract}

Keywords: Social entrepreneur. Formal and non-formal education. Life's history.

\section{Formación del emprendedor social y laeducación formal y no formal: un estudio a partir de narrativas de historia de vida}

\section{Resumen}

Los emprendedores sociales convierten asuntos sociales en oportunidades, crean negocios y transforman la experiencia emprendedora en conocimiento emprendedor. Siendo así, es relevante la comprensión del proceso de formación del emprendedor social como generador de cambios en la sociedad. Este es el objetivo general de esta investigación, que es cualitativa, y cuyo método de investigación involucró el análisis de tres narrativas de historia de vida de emprendedores considerados referencia en el desarrollo de proyectos sociales de impacto en Brasil, según el Premio Emprendedor Social realizado por el diario Folha de São Paulo y por la Fundación Schwab. Para la organización de los análisis, se utilizó el software ATLAS. Los resultados demostraron que la formación del emprendedor social está vinculada a los espacios y contextos de aprendizaje, a la trayectoria de liderazgo y a la motivación para el espíritu empresarial social, siendo que estas categorías están impregnadas por la educación formal y no formal.

Palabras clave: Emprendedor social. educación formal y no formal. Historia de vida. 


\section{Referências}

ADAM, J.-M. A linguística textual: introdução à análise textual dos discursos. São Paulo: Cortez, 2008.

ALBERTI, V. Ouvir contar: textos em história oral. Rio de Janeiro: Editora FGV, 2004.

ALVORD, S. H.; BROWN, L. D.; LETTS, C. W. Social entrepreneurship and societal transformation: an exploratory study. The Journal of Applied Behavioral Science, v. 40, n. 3, p. 260-282, 2004. doi: https://doi.org/10.1177/0021886304266847

APPLE, M. W.; BEANE, J. A. (Comp.). Escuelas democráticas. Madrid: Morata, 1999.

AZEVEDO, A. J. S. Do processo de despolitização das experiências formativas no campo da educação não formal às formas de resistência dos educadores sociais. In: REUNIÃO NACIONAL DA ANPED, 36., 2013, Goiânia. Anais... Goiânia: ANPED, 2013. p. 121.

BITTENCOURT, I. M. et al. Empreendedorismo Social, seus pressupostos e sua aplicação no desenvolvimento de competências. Atas: Investigação Qualitativa nas Ciências Sociais, v. 3, 2015.

BRASIL. Lei $\mathrm{N}^{\circ}$ 9.394, de 20 de dezembro de 1996. Estabelece as diretrizes e bases da educação nacional. Diário Oficial da União da República Federativa do Brasil, Brasília, DF, 23 dez. 1996. Disponível em: <www.planalto.gov.br/ ccivil_03/leis/L9394.htm>. Acesso em: 23 jul. 2017.

\section{CENTRO POPULAR DE CULTURA E DESENVOLVIMENTO (CPCD).}

É possível fazer educação de qualidade sem escolas. 2015. Disponível em: <http://www.cpcd.org.br/portfolio/e_possivel_fazer_educacao_de_ qualidade_100_escola/\#>. Acesso em: 23 jul. 2017.

DEES, J. G. The meaning of social entrepreneurship: original draft: October 31, 1998. Duke [internet]. Disponível em: <https://entrepreneurship.duke.edu/ news-item/the-meaning-of-social-entrepreneurship/. Acesso em: 23 jul. 2017.

DEES, J. G.; EMERSON, J.; ECONOMY, P. Social entrepreneurship. Enterprising nonprofits: A toolkit for social entrepreneurs. New York: John Wiley \& Sons, 2002. 
DIAS SOBRINHO, J. Democratização, qualidade e crise da educação superior: faces da exclusão e limites da inclusão. Educação \& Sociedade, v. 31, n. 113, p. 1223-1245, 2010. doi: http://dx.doi.org/10.1590/S0101-73302010000400010

DORNELAS, J. C. A. Empreendedorismo na prática: mitos e verdades do empreendedor de sucesso. Rio de Janeiro: Elsevier, 2007.

DRUCKER, P. F. Inovação e espírito empreendedor (intrepreneurship): prática e princípios. Tradução de Carlos J. Malferrari. 7. reimpr. São Paulo: Pioneira Thomson, 2003.

FONTES, B. M. Dentista recupera sorrisos perdidos: como num passe de mágica, crianças resgatam a auto-estima; projeto tem 1.050 voluntários. Empreendedor Social (Fábio Bibancos de Rosa). Folha de São Paulo, 2006. Disponível em: $<$ http://www1.folha.uol.com.br/empreendedorsocial/finalistas/2006-fabiobibancos-de-rosa-turma-do-bem.shtml>. Acesso em: 23 jul. 2017.

FONTES, B. M. Moderador de conflitos: advogado cria metodologia para resolver conflitos de posse da terra, com melhoria da qualidade de vida nas periferias. Empreendedor Social (André Albuquerque). Folha de São Paulo, 2008. Disponível em: $<$ http://wwwl.folha.uol.com.br/empreendedorsocial/finalistas/2008-andrealbuquerque-terra-nova-regularizacoes-fundiarias.shtml>. Acesso em: 23 jul. 2017.

FREITAS, H.; JANISSEK, R. Análise léxica e análise de conteúdo: técnicas complementares, seqüenciais e recorrentes para exploração de dados qualitativos. Porto Alegre: Sphinx, 2000.

FREIRE, P. A educação na cidade. 5. ed. São Paulo: Cortez, 2001.

GALVÃO, C. Narrativas em Educação. Ciência e Educação. Bauru, v. 11, n. 2, p. 327-345, 2005. doi: http://dx.doi.org/10.1590/S1516-73132005000200013

GATTI JÚNIOR, D.; INÁCIO FILHO, G. (Org.). História da educação em perspectiva: ensino, pesquisa, produção e novas investigações. Campinas, SP: Autores Associados; Uberlândia, MG: EDUFU, 2005. (Coleção memória da Educação).

GOHN, M. G. Educação não formal, participação da sociedade civil e estruturas colegiadas nas escolas. ENSAIO: Avaliação e Políticas Públicas em Educação, v. 14, n. 50, p. 27-38, jan./mar. 2006. doi: http://dx.doi.org/10.1590/S0104-40362006000100003

HAYEK, M. et al. Effective succession of social entrepreneurs: A stewardship-based model. Journal of Applied Management and Entrepreneurship, v. 20, n. 2, p. 93, 2015. 
ITURRIOZ, C.; ARAGÓN, C.; NARVAIZA, L. How to foster shared innovation within SMEs' networks: Social capital and the role of intermediaries. European Management Journal, v. 33, n. 2, p. 104-115, 2015. doi: https://doi.org/10.1016/j.emj.2014.09.003

JACOBUCCI, D. F. C. Contribuições dos espaços não formais de educação para a formação da cultura científica. Em Extensão, v. 7, n. 1, p. 55-66, 2008.

LEE, R. M.; ESTERHUIZEN, L. Computer software and qualitative analysis: Trends, issues, and responses. International Journal of Social Research Methodology, v. 3, p. 231-243, 2000. doi: https://doi.org/10.1080/13645570050083715

MACHADO, M. A educação de jovens e adultos no Brasil pós-Lei no 9.394/96: a possibilidade de constituir-se como política pública. Em Aberto, v. 22, n. 82, pp. 17-39, 2009. doi: http://dx.doi.org/10.24109/2176-6673.emaberto.22i82

MASKELL, P. Social capital, innovation and competitiveness. In: Baron, S.; Field, J.; Schuller, T. (Ed.). Social capital: critical perspectives. New York: Oxford University Press, 2000.

MASSETO, M. T. Competência pedagógica do professor universitário. São Paulo: Summus, 2003.

MELO NETO, F. P.; FRÓES, C. Empreendedorismo social: a transição para a sociedade sustentável. Rio de Janeiro: Qualitymark, 2002.

MOLDOVAN, O.; BOCOS-BINTINTAN, V. The Necessity of Reconsidering the Concept of Non-formal Education. Procedia-Social and Behavioral Sciences, v. 209, p. 337-343, 2015. doi: https://doi.org/10.1016/j.sbspro.2015.11.245

MOUFFE, C. El retorno de lo político: comunidade, ciudadanía, pluralismo, democracia radical. Barcelona: Paidós, 1999.

MUÑOZ, P.; KIBLER, E. Institutional complexity and social entrepreneurship: A fuzzy-set approach. Journal of Business Research, v. 69, n. 4, p. 1314-1318, 2016. doi: https://doi.org/10.1016/j.jbusres.2015.10.098

NOSELLA, P.; AZEVEDO, M. L. N. A educação em Gramsci. Rev. Teoria e Prática da Educação, v.15, n.2, pp. 25-33, maio/ago. 2012.

OLIVEIRA, I. B. Boaventura \& a Educação. 2. ed., Belo Horizonte: Autêntica, 2008. 
PEREIRA, G. M. C. et al. Panorama de oportunidades para os egressos do ensino superior no Brasil: o papel da inovação na criação de novos mercados de trabalho. Ensaio: Avaliação e Políticas Públicas em Educação, v. 24, n. 90, p. 179-198, 2016. doi: http://dx.doi.org/10.1590/S0104-40362016000100008

PHILLIPS, W. et al. Social innovation and social entrepreneurship: A systematic review. Group \& Organization Management, v. 40, n. 3, p. 428-461, 2015.

RICHARDSON, R. J. Pesquisa social: métodos e técnicas. 3. ed. rev. e ampl. Atlas: São Paulo, 1999.

ROMANELLI, G. O Significado da Educação Superior para duas gerações de famílias de camadas médias. Revista Brasileira de Estudos Pedagógicos, v. 6, n. 184, p .445476, set./dez. 1995. doi: http://dx.doi.org/10.24109/2176-6681.rbep.76i184.1100

ROMEU, G. Educador cria pedagogia do saber popular: cansado da ensinagem, Empreendedor Social 2007 extrapola a sala de aula e cria escola sob pé de manga. Empreendedor social (Tião Rocha). Folha de São Paulo, 2007. Disponível em: $<\mathrm{http}: / / \mathrm{www} 1$.folha.uol.com.br/empreendedorsocial/ finalistas/2007-tiao-rocha-cpcd.shtml>. Acesso em: 23 jul. 2017.

RUIZ OLABUENAGA, J. I.; ISPIZUA URIBARRI, M. A. La descodificacion de la vida cotidiana: métodos de investigacion cualitativa. Bilbao: Universidad de Deusto, 1989.

SASTRE-CASTILLO, M. A., PERIS-ORTIZ, M.; DANVILA-DEL VALLE, I. et al. What is different about the profile of the social entrepreneur? Nonprofit Management and Leadership, v. 25, n. 4, p. 349-369, 2015. doi: https://doi.org/10.1002/nml.21138

SAVIANI, D. Instituições Escolares: conceito, história, historiografia e práticas. Caderno de História da Educação, Uberlândia, n. 4, jan./dez. 2005.

SLOAN, P.; LEGRAND, W.; SIMONS-KAUFMANN, C. A survey of social entrepreneurial community-based hospitality and tourism initiatives in developing economies. A new business approach for industry. Worldwide Hospitality and Tourism Themes, v. 6, n. 1, p. 51-61, 2014. doi: https://doi.org/10.1108/WHATT-11-2013-0045

SOUSA, E. G. et al. O perfil do empreendedor social e suas dimensões de atuação: um estudo de seis casos no município de Uberlândia-MG. In: Encontro da ANPAD (EnANPAD), 37., 2013. Anais... Rio de Janeiro: EnANPAD, 2013. p. 214. 
TACHIZAWA, T. Organizações não governamentais e Terceiro Setor: criação de ONGs e estratégias de atuação. São Paulo: Atlas, 2002.

VAN DER LINDEN, J. Non-formal education and new partnerships in a (post-) conflict situation: 'Three cooking stones supporting one saucepan'. International Journal of Educational Development, v. 42, p. 54-62, 2015.

VIEIRA, R.; VIEIRA, A. M. Usos e abusos do formal e não formal em educação Uses and abuses of formal and non-formal education. Revista Série-Estudos, v. 21, n. 41, p. 14-29, 2016. doi: http://dx.doi. org/10.20435/231819822016102

WIEVIORKA, M. Em que mundo viveremos? São Paulo: Editora Perspectiva, 2006. (Coleção Estudos 2015).

WILLEMS, J. Individual perceptions on the participant and societal functionality of non-formal education for youth: Explaining differences across countries based on the human development index. International Journal of Educational Development, v. 44, p. 11-20, 2015.

doi: https://doi.org/10.1016/j.ijedudev.2015.07.003

\section{Informações dos autores}

Lucimar da Silva Itelvino: Doutora em Educação pela Universidade Nove de Julho (Uninove). Coordenadora e Professora do Curso de Graduação em Administração da Uninove. Contato: lucimarsilva@uninove.br

Priscila Rezende da Costa: Doutora em Administração pela Universidade de São Paulo (FEA-USP). Professora do Programa de Pós-graduação em Administração e do Curso de Graduação em Administração da Universidade Nove de Julho. Contato: priscilarc@uni9.pro.br

Maria da Glória Gohn: Doutora em Ciência Política pela USP e Pós-doutorado em Sociologia pela New School University. Professora Titular da Unicamp do PPG em Educação e Professora Visitante Sênior da UFABC. Pesquisadora 1A de Bolsa Produtividade do CNPq. Contato: mgohn@uol.com.br

Claudio Ramacciotti: Doutor em Administração de Empresas pela Fundação Getúlio Vargas (FGV-SP). Professor do Curso de Graduação em Administração da Universidade Nove de Julho. Contato: claudior@uninove.br 